\title{
Motherhood and genetic screening: a personal perspective
}

\section{Fiona Place}

\section{According to the medical profession the direction and scope of reproductive services such as IVF and pre-natal} screening are based on solid evidence; the evidence indicates these are effective and safe services. Moreover, women want them. As a consequence these services are usually presented to the wider community in a positive light with images of 'successful' birth outcomes showcasing the importance of their work. Unsurprisingly this has lead to women being expected to take control - from timing a pregnancy to choosing one particular pregnancy over another - they are to improve their lives and the health of their offspring. But are these developments all 'good' news? Is it safe to assume the push to achieve better birth outcomes and the concomitant use of prenatal testing automatically improves lives? Could it be the issues raised are causing some lives to become harder? How meaningful, for example, are tests such as amniocentesis and CVS? As the mother of a child with Down syndrome I believe it is important for myself and other women in similar situations to share their lived experience. Perhaps we can illuminate some of the more complex and troubling issues these technological advances have the capacity to create - not only for ourselves - but for all women.

Motherhood. It's no longer as simple as getting married and having babies (if it ever was). These days women are expected to take control of their lives. To project manage their pregnancies and childrearing commitments.

In the seventies the pill provided women with sexual and reproductive choice. They could, amongst other things, choose the timing of any pregnancy. Today, reproductive services such as IVF and pre-natal testing are presented as enhancing this choice. As offering women the opportunity to choose one particular pregnancy over another, to further improve their lives and the health of their offspring.

And generally speaking as a society we expect women to avail themselves of these services, to submit to the various screening programmes.

But how informative are medical procedures such as amniocentesis and CVS? How meaningful are the results? And more importantly, how safe is it to assume prenatal testing improves lives? Could it be, for example, that some lives are becoming increasingly more difficult as screening methods become simpler and more affordable?

The issues are complex and the answers necessarily different for each of us.

As one mother who has grappled with the issues surrounding prenatal testing I would like to share with you a few of my experiences and hopefully illuminate some of the more complex and troubling issues these technological advances have the capacity to create.

\section{In the seventies the pill provided women with sexual and reproductive choice. Today, reproductive services such as IVF and pre-natal testing are presented as enhancing this choice.}

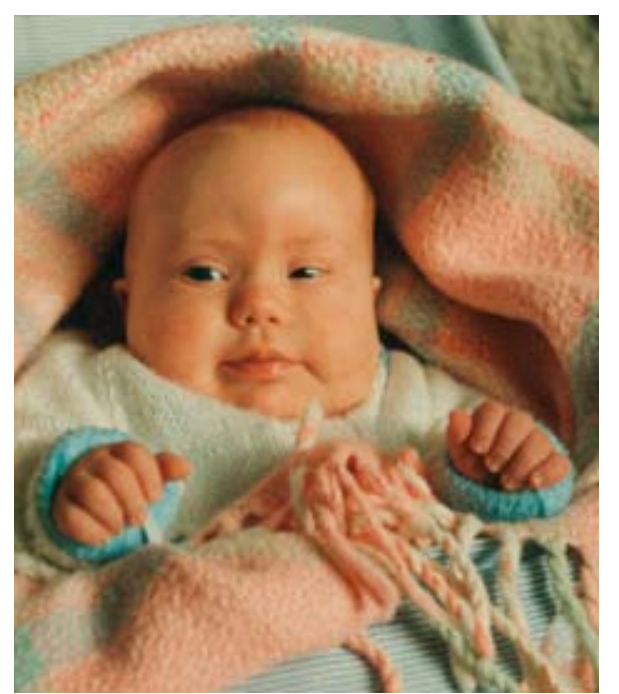

\section{Living with Down syndrome}

There are days when having a child with Down syndrome can mean losing all hope of being an ordinary mother; a mother with run of the mill concerns, a mother with run of the mill routines.

\section{I know.}

I've had such days.

Days when I wish I were a mother who could meet up with other mothers at the park, a mother who could entertain the possibility of returning to full-time work, or a mother who could take her children to the beach on a hot summer's afternoon.

Days when the longing for a sense of ordinariness, the longing to be a mother who isn't that much different to other mothers threatens to extinguish any sense of usefulness, any sense of belonging to a community outside the family walls.

Periods when being confined to the perimeters of the home while trying to be a good enough mother to three mediumsized boys can seem unduly difficult and unduly friendless.

Fortunately, such bleak times are few and far between. And most of the time I feel good about our lives. Most of the time I feel ordinary enough as a mother, connected enough as a mother despite my limitations. 
However, I would be lying if I said I'd never felt so devoid of hope, so overwhelmed by the job of caring, and so alone, that I haven't asked myself the hard question, the unpalatable question.

Would I, had I known Fraser was to be born with the chromosomal disorder known as Down syndrome, have terminated my/his pregnancy? Or put another way, should I have done what was expected of me? Should I have had the amniocentesis?

The answer I have always given is no. No, no and no.

\section{Fraser's pregnancy}

I fell pregnant with Fraser unexpectedly at the age of thirty-seven. I was already a mother to Harrison, a fifteen-month year old, and although the pregnancy took me by surprise, I was delighted, as I'd always planned to have a second child.

It was a similar story the second time around - I had cramping every now and then, spotted a bit here and there, but made it to the sixteenth week mark and what was back in 1995, the first routine test for any chromosomal abnormality, the maternal serum alpha-fetoprotein (AFP) blood screen.

I took the test as a matter of course. It showed I was at high risk of having a child with Down syndrome. However I wasn't particularly concerned.

I'd had a similarly high risk reading when I was pregnant with Harrison. The risk with Fraser appeared slightly higher, but other than knowing we would have to find time to see the genetic counsellor again, I didn't dwell on it.

Christopher and I had visited the genetic education centre two years earlier to discuss the significance of Harrison's test results.

My risk had been reported as 1:150. And in 1993 anything above 1:250 was considered high risk. It was the line in the sand. The ratio geneticists had set as the alarm bell.

It was the point where the number of babies detected with Down syndrome outweighed the number of babies that would die as a result of their mother taking the test. The site where the death/detection rate crossed over.

We'd sat in the office and told the counsellor that Harrison's routine ultrasound scan at eighteen weeks had shown noth- ing untoward. That he'd passed with flying colours.

We were aware however, that since more than half of all significant foetal abnormalities are often missed on the scan, the fact nothing suspicious had been found could count for little. That a seemingly perfect score might have generated a false sense of reassurance. A false sense of hope.

So we'd listened to the risk. Detected the unease in the counsellor's voice as she described the particular catastrophe into which we may be heading, the real possibility I might be carrying a foetus affected by Down syndrome. We could, she advised, avoid the danger. We could make a decision right then and there to head for calmer waters.

\section{"The counsellor had alarmed us, but we were fairly unmoved. \\ The odds were still in our \\ favour and we didn't want to expose ourselves to the risk of miscarriage or infection."}

We then spent the next hour or so in the hospital café - talking and sipping coffee. The counsellor had alarmed us, but we were fairly unmoved. The odds were still in our favour and we didn't want to expose ourselves to the risk of miscarriage or infection. We were happy enough to steam ahead - and if the baby did have Down syndrome - so be it. Needless to say, the counsellor was taken aback by our decision to decline the offer of certainty.

And it seemed the second time around with Fraser it would be pretty much a similar scenario; once again we'd tell the counsellor nothing untoward had shown up on the ultrasound scan, once again we'd listen to the risk spiel and once again we'd decide to sail forward. So I phoned and made an appointment.

\section{Visiting the genetic education centre}

on the day of the appointment, in a joyous mood and proud of my pregnancy, I wore a dress. My good maternity dress. My attending important and less important events dress. My yes I am pregnant dress. It was one of the few maternity purchases I'd allowed myself during my second pregnancy and whenever I wore it I felt special. A pale soft blue; it was a light, flowing and possibly a little too short. But I always felt deliciously pregnant inside it. Deliciously fecund and incredibly sexy. Especially when a foot or hand kicked against the wall of the womb or I felt the sudden swish of a speedy somersault.

I also wore a matching pair of under garments - a rare pleasure indeed - as most of my collection only match on what could best be described as the vaguest of criteria.

We sat in the same office with the same counsellor and once again listened to the risks. A normal foetus, as you both know, has 46 chromosomes in each cell. But given your high AFP reading Fiona, there is a significant risk that instead of 46 there could be 47 chromosomes in each cell. Each cell could be carrying an extra copy of chromosome 21.

And as you both know, she continued her voice deepening; Trisomy 21 is associated with mild to severe intellectual disability. It also increases the risk of childhood leukaemia; certain cardiac disorders and is associated with other genetic disorders such as Hirschsprung's disease.

We listened and once again decided to have a coffee in the hospital café.

This time however the tone was different, this time we could feel the high-octane spiel, feel the pressure pound through our bodies, pulsate through our veins - we should take the test, we should take the test, we should take the test.

We were, were we not, intelligent, welleducated and responsible human beings? Surely we could understand the need to invade, the need to extract a sample of amniotic fluid? Surely there were no ifs and buts this time? Surely we understood the need for certainty; for reliable and accurate information?

We did and we didn't.

We knew for example, that even if we ruled out the possibility of Down syndrome there was no guarantee our baby would be normal. We'd done our research. We knew that of all the children born with an intellectual disability only twenty five percent have a prenatally detectable chromosomal disorder such as Down syndrome.

In other words, the majority of mothers who give birth to a child with an intellectual disability will have received perfectly normal, utterly reassuring amniocentesis 
results. They will have put themselves at risk and will have been rewarded with good results. They will have been expecting a baby they could cherish, a baby they could feel proud of - a baby they could love.

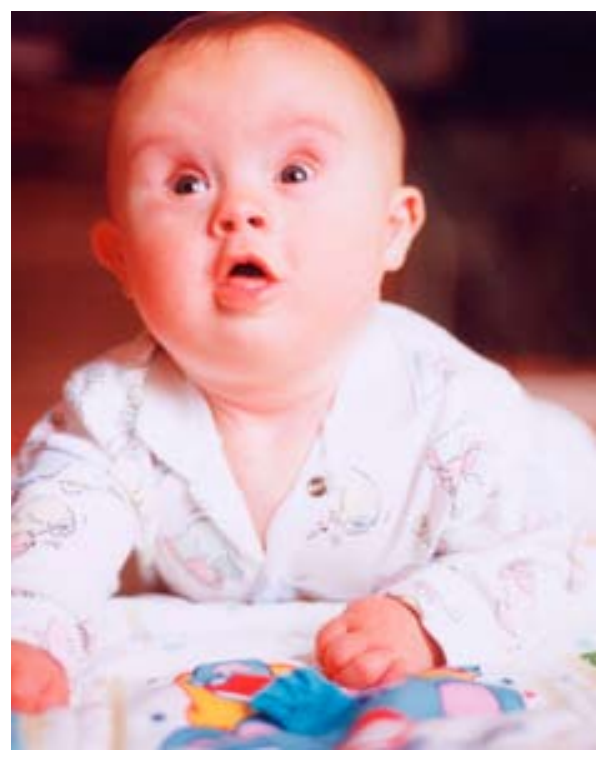

\section{Victoria's experience}

I had met such a mother at the playgroup I attended with Harrison. Victoria was around the same age as me, possibly a little younger and in her pre-children life had worked as a department store buyer. I still remember the morning I arrived early to playgroup and she and I somehow managed to fall into a very personal conversation.

Victoria was sitting down on one of the picnic rugs set out for us with her daughter Sarah and signalled for me to join her. So I quickly let Harrison out of the stroller and sat down next to her and Sarah on the rug.

Harrison scanned the opportunities that lay ahead and then made a beeline for the box of wooden blocks. He sat down next to the box, pulled out the blocks he wanted and with what appeared intense concentration began constructing. Little hands carefully placing block after block.

I could sense Victoria's gaze.

Watching him at work is so compelling, isn't it? She offered.

Yes, I replied, sensing her desire to keep the focus on him.

Looks like a castle, Victoria smiled. My Thomas was just like him at that age. He could always entertain himself for hours. Now he's into books, computer games and sport. Victoria talked at length about Tho- mas.

I managed to say a bit here and there about Harrison, but I couldn't help feeling I should at least mention her daughter Sarah.

I knew most of the mothers in the group avoided Sarah, that they did their best to politely ignore her. To ignore the fact that unlike the other two year olds she could neither walk nor talk and looked odd.

Sarah had a small, misshapen head and her hair, the little in evidence, was wispy and uneven. Unfortunately, this and her small stature only accentuated her lack of development. And no amount of expensive camouflaging, of Baby Gap or Osh Kosh outfits could disguise her differences.

Victoria would always arrive with a hat in hand, but Sarah would always fuss and no matter how firmly Victoria placed her cap or sun-hat on she would always manage to pull it off. Usually within minutes.

It must be hard with Sarah, I said, hard day to day. I wasn't sure if it was the right thing to say, but I wanted Victoria to know I was OK about talking about Sarah, if she was OK talking about Sarah.

It is, Victoria replied, but you know what's really hard, what's really hard is knowing I would've done something had Sarah's condition been identified, had the prenatal tests been able to detect something like Down syndrome. Then lowering her head she stopped herself and began apologising.

\section{"I knew most of the mothers in}

the group avoided Sarah, that they did their best to politely ignore her. To ignore the fact that unlike the other two year olds she could neither walk nor talk and looked odd."

There's no need, I replied, trying to comfort her by placing a hand on her shoulder.

My husband didn't want a child with a disability, she told me. In fact John still doesn't want a child with a disability. I don't need this, he tells me whenever I try to talk to him about Sarah. Some days, she confided, some days I feel so angry they can't figure out what's wrong with Sarah I loath everyone.

Sitting up stiffly, she pushed her hair back off her face and let out a deep sigh.
Only God knows, she told me, only God knows if my marriage will last, or I'll be able to keep caring for Sarah.

I left my hand on Victoria's shoulder, not sure what to say. I wanted to say something, to reach out, but all I could come up with was to repeat that it must be hard. So hard.

Victoria nodded and leaning over towards Sarah, gestured for her to take a sip of her drink. Sarah refused. And screaming loudly pushed the beaker and her mother's hand away. Victoria tried several more times, but no matter how she approached her daughter she could not persuade Sarah to drink. She drank yesterday, she told me, a mixture of pride and exasperation in her voice, drank by herself for the very first time.

She did, did she? I responded, hoping I'd got the tone right. I also found myself wondering what must be like to have a daughter like Sarah and a husband like John.

A daughter who through no fault of her own was identified by all and sundry as a source of unhappiness. And a husband who not only joined in the chorus of dismay, but seemed to feel free to voice his disappointment without any consideration for those around him.

It's always such an issue, Victoria told me, always a struggle to make sure she eats and drinks enough. I nodded. Perhaps one day, she added, perhaps one day I'll have to choose - Sarah or John. I don't know, maybe the choice will be made for me.

The pain in her voice was unbearably sad, unbearably lonely. But with the other mothers arriving and the empty spaces on the picnic rug quickly filling up, the conversation turned to more commonplace concerns.

It did seem a particularly unenviable situation - the presence of the prenatal test and its meaningless results - having added a sharp layer of complexity to Victoria's relationships.

From the outside it seemed her undergoing the amniocentesis had created knots she couldn't untie. Knots which accompanied her every second of the day. And while she stopped coming to the playgroup not long after our conversation, I had not forgotten her.

Her guilt and doubts had stayed with me. 


\section{Our decision}

The chairs in the hospital café were not comfortable, were not designed for a lengthy stay. We had to make up our minds.

Should we relent this time? Should we accept the professional advice? We talked and we talked.

We knew if we agreed to the amniocentesis it would only rule out Down syndrome - or a less common chromosomal disorder such as Trisomy 18 or Trisomy 13.

But little else.

Four thousand other known birth defects would still remain.

Defects such as attention deficit disorder, cleft lip, cleft palate, clubfoot, congenital cardiac disorder, cystic fibrosis, epilepsy, . . . would not magically disappear by agreeing to the test. Neither would the possibility of giving birth to a child with autism or cerebral palsy. Or a child with vision, hearing or speech impairment. Neurological problems, skin problems or behavioural difficulties ...

\section{"I knew it was common practise} to only publicly announce

a pregnancy once you were certain the baby you were carrying didn't have Down syndrome."

We were however strongly aware the drive to have a normal child was expected of us. That we were making our decision at a time when social and economic imperatives dictated that we should want the best. The best partner, the best career, the best house ... the best baby.

We had already agreed to a blood test and an ultrasound, so why not an amniocentesis? Why stop now? Why not proceed with a test most women over the age of thirty-five consider essential?

What was wrong with me?

I knew it was common practise to only publicly announce a pregnancy once you were certain the baby you were carrying didn't have Down syndrome. Was I, I wondered, hesitating because everyone already knew I was pregnant? Because I might look silly for not having kept it a secret?

No. No, I balked because the test would only rule out Down syndrome.
Would only rule out a chromosomal abnormality.

It may sound strange, but for me this made the test seem both too specific and not specific enough. Put simply, it didn't engage me. I didn't want my baby singled out for scrutiny. I didn't want to insert a metal needle into his or her home, into my womb. I couldn't justify the risks.

There was also a far larger obstacle.

I knew if I agreed to the test and the words chromosomal disorder were to appear - a certain set of assumptions, an as yet unspoken trajectory would swiftly emerge. And I wasn't sure I would be able to follow its course.

There were things in my past that made me doubt my capacity to respond.

\section{Beyond the test}

I knew if the test results came back positive I would be expected to terminate immediately. To abort my affected foetus. The fact I could find it difficult to fall pregnant again after the termination or that any future foetus may also be affected by a birth defect would make little difference. Out the four thousand known birth defects it would be considered imperative not to proceed with this particular one.

And following on from that logic it would be assumed the how; the business of termination would be of little importance to me given the perceived gravity of the situation. I would want to solve the problem by removing it. No matter what.

Before the procedure (as it would be referred to) the staff would want to reassure me, would want to comfort me - and in soothing voices tell me that yes; yes of course this procedure is in your best interests. You and your baby shouldn't be made to suffer, not now or ever. You're doing the right thing, they would reassure me, you are.

But what would be left as unsaid would be the unavoidable realities of termination.

On the elected day, during what would be the twenty-second week of my pregnancy, I would have to consent to the induction of labour. Simultaneously, I would also be expected to consent to a foetal intracardiac injection of potassium chloride to ensure the delivery of a dead baby.

I would be advised to give birth to a dead baby because it would be considered better if I didn't hear the baby cry. Better if

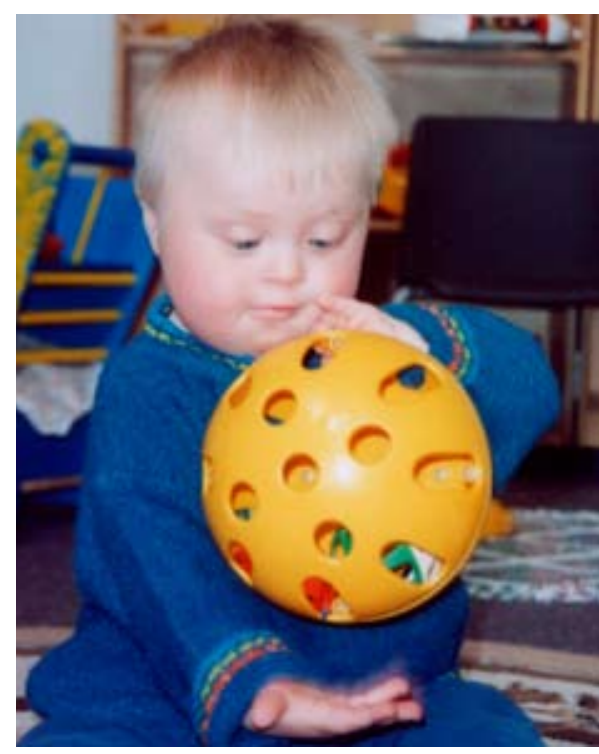

I didn't see the tiny creature breathe. Or try to breathe. The staff would also prefer I consent, would prefer I minimised everyone else's distress. Then after the event I would be left alone. Left alone to my own devices. Left alone with no baby.

I would be promised a tiny set of foot and handprints as a memento of my once vibrant pregnancy. And expected to be grateful, to be thankful, for the successful elimination of a pending disaster. But while I knew the staff would mean well, would believe they were doing the right thing for me, I knew it wasn't the road for me. That I just couldn't do it.

We spent considerably longer in the café the second time. And even though we tried to keep things light, we were both subdued. Both tense. My reading had come back as 1:120. Yes it was slightly higher but did it mean anything? Our conversation was full of bumps and long winding trails.

Finally though, after approaching the decision from this angle, that angle and every other angle we could think of we both felt there was little more to say. And agreed we may as well return to our genetic counsellor.

My special pregnancy dress doesn't feel quite so special or sexy, I complained to Christopher as we neared the entrance to the centre.

It'll be OK, he whispered, and taking my hand, held it firmly in his. I took pleasure in the warmth of his flesh and a small portion of the pride the dress usually engendered, slowly re-emerged. On our return we were immediately ushered into the counsellor's office. 


\section{The pressure to conform}

Welcome back, she smiled. I'd like to introduce you to Dr M. I nodded politely in the doctor's direction while immediately trying to discern if Christopher felt as caught off guard as I did. You'll be pleased to know Dr M can perform the test today, she informed us.

Dr $M$ nodded and reached out to shake my hand. It's a bit of a squeeze, she told me, but I can fit you in at around four. And don't worry; she reassured me, that's what we're here for.

I was shocked the heavy artillery had been called in. The pressure to conform, the pressure to say yes had been dramatically heightened by the presence of a doctor in the room. I could also sense the two women wanted to talk to me alone. That they wanted to talk woman to woman, that they thought if they could get me on my own I would agree, I would understand. That it must be the male who was the stumbling block. The problem. But I could also tell they were unsure; Christo-

\section{I could also sense the two} women wanted to talk to me alone. That they wanted to talk woman to woman, that they thought if they could get me on my own I would agree, I would understand.

pher was after all a doctor, a member of the health profession, one of them. Surely, they reasoned, surely he must understand why I must take the test.

I didn't want to talk to them alone. In part, because I felt the decision was as much Christopher's as it was mine. Perhaps a little more mine, but one I wanted to make together. And much to their dismay I declined both the talk and the amniocentesis.

Well, if you change your mind we're here the counsellor reassured me. I nodded and as I left I made a point of looking each woman in the eye while shaking her hand firmly. Thank you, but no thank you, I reassured them.

I wanted the baby I'd felt kick. I wanted him or her no matter what.

I don't know why, but the prospect of giving birth to a baby with Down syndrome didn't terrify me.

\section{Caring for sick children}

As a twenty-three-year old student paediatric nurse I'd cared for sick children. Children with everyday illnesses such as gastroenteritis, croup and the flu. As well as children with more serious ailments such as cystic fibrosis, whooping cough and leukaemia.

I enjoyed looking after all of them, but for some reason it is the children I met in the neurology ward that I remember the most. The children who had brain tumours, epileptic seizures, or neurological damage caused by trauma. It certainly wasn't an easy ward to work on.

Often I would find myself nursing a child who would never be the same again. Who would forever struggle with the effects of brain injury. Or more heart breaking, nurse a child who was terminally ill. It was physically and emotionally challenging work. But it was also immensely rewarding, especially if you believed what you did could make a small difference for a child or parent.

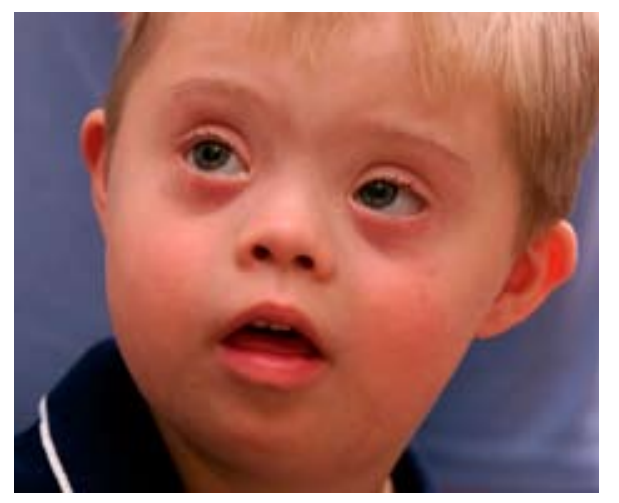

\section{Samuel's accident}

I still have clear memories of nursing Samuel, a three-year-old boy recovering from severe head injuries he'd received in a car accident. His parents had been killed instantly when an oncoming vehicle had veered off course and rammed head on into their station wagon.

I spent as much time with Sam as I could. Reading, playing and hopefully providing some comfort, some distraction. I was able to do this because back when I was a student nurse it was considered the right thing to do - as long as you still completed all your non-nursing tasks. In the early eighties simply spending time with a child was considered an important part of the healing process. It wasn't like today where over-stretched nurses haven't even the time to feed a patient, let alone read to one.

Sam's recovery was painstakingly slow. The medical staff wanted to remove his intravenous drip, but before that could be done he had to be drinking. The fluid intake via the drip had been lowered so as to increase his thirst, but he just wasn't interested. Eventually, the Charge nurse decided he should be offered a smartie for every $15 \mathrm{mls}$ he swallowed. But even with the offer of whatever colour he wanted, Sam still wouldn't drink.

I still remember the combination of silly games and soothing words I used to cajole him. And how excited I was when he swallowed those first $15 \mathrm{mls}$ and reached out to choose his first smartie. He picked out a red one. And breaking into a small smile pushed it into his mouth. As he began to chew I couldn't resist leaning in over the bed rails and giving him a hug.

Each day I would arrive on the ward and hope Sam had been assigned to my care. If he and I were going to spend the shift together I would feel immense pride - as though I had been chosen specially. It wouldn't matter that the Charge nurse had probably assigned each Junior nurse according to their workload and experience; I still liked to think it was me she was choosing.

These days as a parent I look back wonder if I spent time thinking about Sam's future. I have no specific memory of worrying about the years ahead, worrying about what sort of a recovery he would make and how well his grandparents would cope. Perhaps I did think about how life might turn out for him. Or perhaps since mine was still in the process of unfolding I didn't know how to imagine the future. I can only hope my care was good enough even if I couldn't understand the bigger picture.

\section{The memory of Hannah}

Another far more painful and troubling memory is that of six-year-old Hannah. Hannah arrived on the ward one Christmas Eve. She had been complaining of tiredness and headaches and had become increasingly irritable and difficult. Initially, her parents Steve and Rachael thought she going through a phase that she was unhappy at school, but as her condition deteriorated it soon became clear she was seriously unwell. And a brain tumour 
had been diagnosed.

On Christmas Eve it was placing a lifethreatening amount of pressure on her brain.

As we were wheeling Hannah to the operating theatre Rachael gently stroked her face and talked softly to her. I handed Hannah over to the theatre staff and was about to wish her parents well when Rachael pulled me aside and began to cry. Did I think Hannah would live? Did I think she had a chance?

To this day I don't know what I said to Rachael. I have no memory whatsoever. My only hope is that I said something comforting. Something kind.

The pressure on Hannah's brain was relieved during the operation, but her brain tumour was to prove incurable. No amount of treatment could alter the course of events we all knew lay ahead.

During her stay with us she looked out for every other child, always letting us know if they were in pain or needed something. She never complained, not even when she lost her sight. Her mother was equally as brave.

She refused to dwell on the future. Instead she worked hard to make the present as open as possible, as full of love as she could make it. And when it came time to say goodbye to Hannah she encouraged each of us to spend some time alone with her, even though she knew her daughter only had hours to live.

Now, twenty-five years later, I still cherish those moments. Still marvel that I was allowed to participate in those families' lives. I am also still grateful that the prevailing climate of the day expected me to dive down deep into the nursing experience. To plunge head long into a total life experience.

At the time I loved the work on the ward with the children, but decried the oppressive nature of nursing officialdom. And midway through my training decided to leave. Usually such an action was frowned upon, but thankfully I had the blessing of the Matron who took my hot-headedness in her stride and suggested I return when nursing was a tertiary degree.

I never did end up returning. Instead I went on to become a writer first tackling poetry, the short story and the novel. And later in my career non-fiction and journalism.

I never thought nursing managed the change to a tertiary degree. That in the drive to gain credibility in the academic world, it seemed to lose too much of what had made it work in the apprentice-based style of learning - the clinical component watered down to the point of anaemia. So lacklustre it wasn't worth doing.

However the intense experiences I did have in that short period of time were pivotal in shaping my future capacity to manage so many life experiences especially motherhood. Not only did I have to learn to cope with long and tiring shifts, but I also had to accept what I could and couldn't change.

Illness and disability were normalised.

They no longer seemed two separate states.

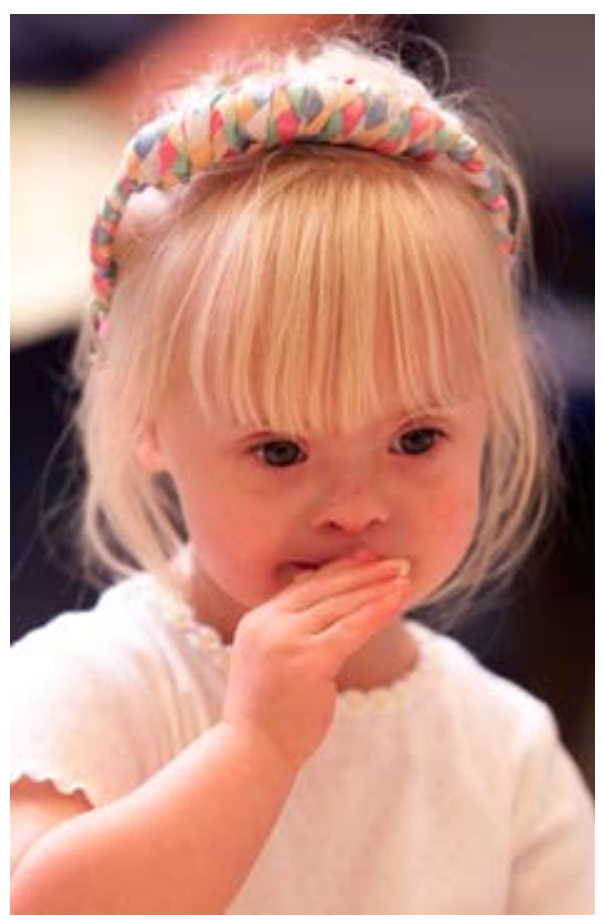

\section{My sister's experience of disability}

Perhaps the prospect of having a baby with Down syndrome didn't terrify me because my sister had a disability. Not that we ever really referred to it as such, it was only ever Alison's epilepsy. And although it was uncontrollable for most of her childhood, my mother tried to make her life as normal as possible. She was allowed to ride a bike, climb trees and swim. But it wasn't easy for my mother because even though she wanted my sister to live a normal life there were no support services. Only a somewhat pessimistic neurologist.

No one made the link between my sister's declining school performance and her epilepsy. That she would lose the thread of a conversation because of a brief petit mal, a brief moment when she wouldn't know what was going on. Or that repeated grand mal seizures took away her capacity for abstract thought and made her more and more concrete in her thinking. But despite the lack of support my mother worked long and hard to bring up a daughter who could hold down a full time job and live independently. She refused to let her use her epilepsy as an excuse.

So much so that even today I still find it difficult to say my sister had a disability. I didn't grow up with the word and my sister herself rarely used it to describe herself. Not surprisingly she went into the field herself working at first as a residential worker in a special school for disabled children and later as a rehabilitation counsellor for the Royal Blind Society.

\section{Premature babies}

I don't know why, but I couldn't understand why a baby with Down syndrome was something to be avoided at all costs while a baby who was born prematurely and likely to emerge from the labourintensive incubator process with severe life-long disabilities was cherished, welcomed and saved no matter what the expense.

Other than being normal to begin with - where was the difference?

Perhaps it was the possibility the premature baby might emerge unscathed. That hope remained. That there was a real possibility the intense and expensive process of saving the baby might not cause any damage.

Whereas with Down syndrome the damage was done. The damage was known.

I don't know. Perhaps even with Down syndrome I felt there could be hope.

Hope that the child might only be mildly intellectually disabled. Might not experience any of the serious medical complications. And that new and innovative treatments would be discovered in their lifetime.

\section{I don't know.}

I just couldn't accept the conventional wisdom. Couldn't accept the need to test.

My commitment to this response has always been solid. I have never doubted my decision, never thought I should've taken the test. 


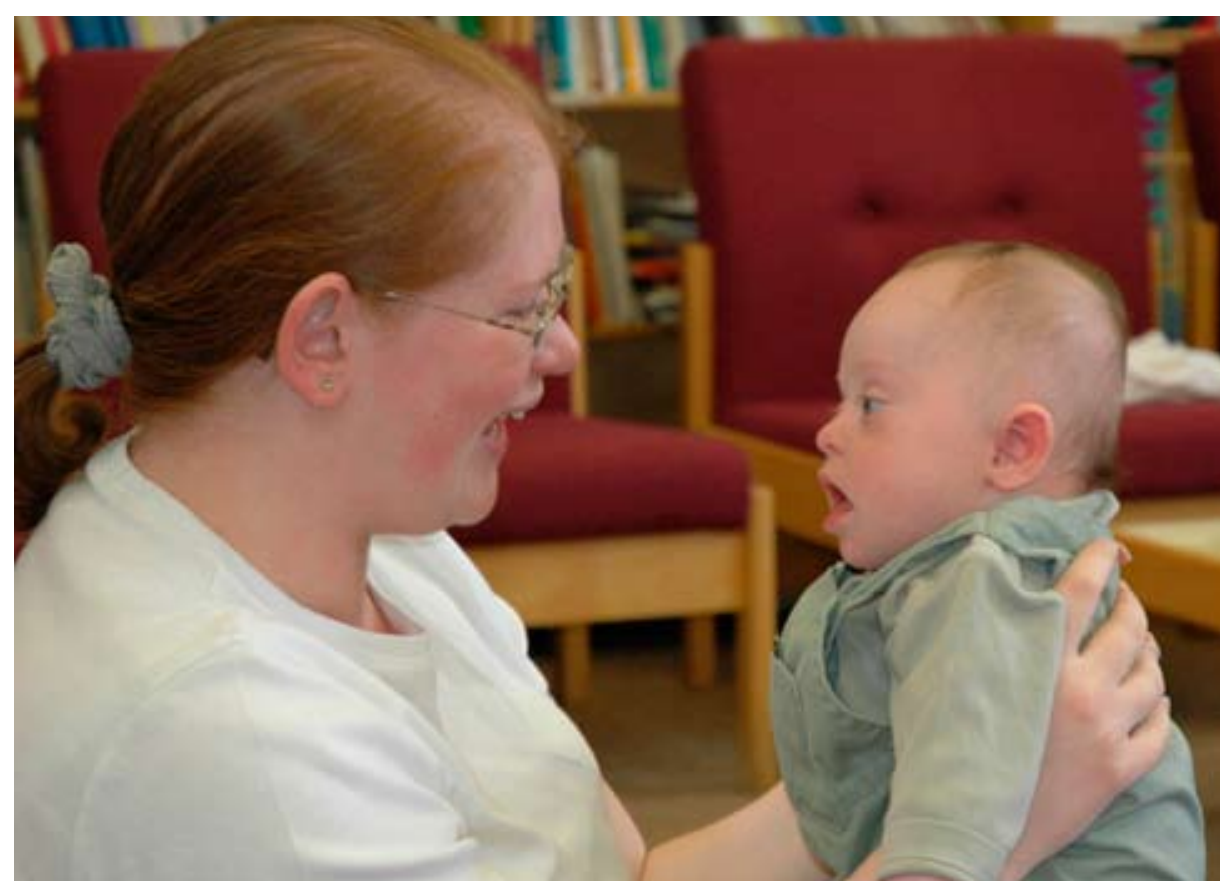

Yes it has been hard. And in many ways far, far harder than I ever could have imagined.

\section{Falling pregnant again}

So hard in fact that when I fell pregnant for a third time in 1999 aged forty-one I did relent. I did revisit the world of testing.

By then the nuchal translucency screen, an ultrasound where they measure the thickness of the neck was the latest advance in the detection process. However just as the results of the maternal serum alpha-fetoprotein blood screen had been of little use, so too were the results of the ultrasound. I was too old, already within a too higher risk group for the test to have any value.

The only tests with any certainty were still invasive: amniocentesis or chorionic villus sampling. CVS, which involved taking a piece of the placenta, could (by then) be done earlier in the pregnancy and was slightly less risky. More importantly, the results, if I were willing to pay extra, could be made available before the end of the twelfth week. Before my line in the sand.

Should we test this time? Should we? It was an extremely painful decision. What would taking the test say about Fraser? What message would I be giving him and his brother?

And what about work?

I loved writing my weekly finance column for the Australian. I loved working at home part-time. If Fraser was sick and home from childcare I could tap away in between administering love and medicine. Or work while he slept. And if he ended up in hospital as he often did I could always take my laptop with me. In many ways work was my anchor, the one thing that went on regardless. Managing a third child would already push me to my limit, but a child with Down syndrome? Would I be able to keep working?

Christopher and I lay awake night after night. We cried, we talked and held one another. It was unbearably sad. I didn't want to have to make the decision.

The pregnancy was hard fought - being older I had found it harder to conceive and harder to hold onto a pregnancy past the eighth week. And on the day we visited the genetic education centre it was touch and go as to whether I would test.

It was the same counsellor. The same office, but this time Christopher took the lead and gently suggested it probably was the right thing to do this time. Probably in our best interests to take the test. I was hesitant at first and a bit surprised, but enormously thankful. I needed him to help shoulder the decision. I couldn't have made the decision alone - I needed his support.

Immediately after the procedure I started cramping, painful cramping and it was feared I might miscarry. Fortunately three days resting saw the pain remit and the results - a chromosomally normal child - arrive. It was bitter sweet. I was relieved, but I knew I wasn't out of the woods, that the baby could still have or develop a wide range of conditions. Autism, cerebral palsy, ADHD ...

I can also say that to this day I still don't know what I would have done had the foetus, had Aidan, been shown to have an extra chromosome, to have the condition Down syndrome.

I may have terminated.

I may have decided one child with Down syndrome was all we as a family could manage. That it was a journey best kept special, best kept for only one of our children.

I certainly don't like dwelling on how I would have felt had I miscarried as a result of the test, as a result of my desire to know, to do the right thing.

As it was Aidan is fine - in fact more than fine and just like his brother Harrison is gifted. And it is wonderful to have a brother for Harrison who can match him intellectually. In many ways you could say the decision to have a third child was one of our best. It allowed us to move on from the sadness and heartbreak and surround Fraser with love.

I began and finished my family in the same way most women do - with a normal, ordinary child.

However there are days when having a child with a disability magnifies the everyday difficulties. Magnifies the smallest of tasks. For example, doing Harrison's school drop off for the first three years after Aidan was born, meant having to use a double stroller to take Fraser and Aidan from the house to the car because it was too dangerous (on my own) to do otherwise.

I would walk the two of them out to the car. Unstrap them from the double stroller and strap them in their car seats for the short trip to the school. Park. Pull the double stroller out of the boot. Lock Aidan and Fraser in for the short walk to Harrison's classroom. Walk back out to the car. Strap both of them in their car seats for the short trip to Fraser's childcare. Park. Pull the double stroller out of the boot. Lock Aidan and Fraser in for the short walk to Fraser's room. And in the afternoon I would repeat it again with military precision. If it rained we got wet. If there were no parking spaces close by we had to wait. If Harrison got embarrassed because his five-year-old brother was in a stroller and making silly noises he had to get over it.

Over the years the difficulties have 
changed. These days it is more a case of not being able to carry Fraser and getting stuck somewhere. Stuck at Woolworths. Stuck at a friend's house when I go to pick up Aidan or Harrison. Or stuck in the middle of the local public swimming pool.

Of not being able to go out easily as a family.

But despite these problems I have never thought I should have done differently.

\section{Loving Fraser}

I love Fraser. I love that at the age of ten he can now take himself to the toilet in the morning, do up his own seatbelt, get dressed as long as the clothes are already turned the right side out and have no buttons, understand much of what I say and respond using five word sentences. I love that he no longer wears bands on his legs or spends time each day in a standing frame, but can walk himself out to the car.

I love that he can swim in the surf, run after his brothers and catch a ball.

I love that I pick him up in the car line up with my other two boys and that he is the first child with Down syndrome to attend the school.

I love that he begs me to take him to the DVD store.

That he loves the Simpsons, Futurama and Star Wars. And sausages, orange juice and tomato sauce sandwiches.

I love that he enjoys life in a way I never do - totally in the present - always in the now.

However during a recent unexpected reexamination of the issue. And under the harshest of microscopes, I cracked.

Faltered.

And feelings I thought were too small too see, too small to pinpoint, broke out and forced their way towards the surface.

\section{Questioning my decision}

I was lying on the bed with Christopher one evening talking about a fiftieth birthday party we'd recently attended, when without any forewarning, without any awareness I was heading into emotionally dangerous territory, I found myself recounting one of the many conversations I'd had that night.

The woman I was sitting next to, I told him, on finding out I had a child with Down syndrome and listening to me talk about how emotionally difficult I would've found it to have terminated the pregnancy at twenty-two weeks, surmised that I must be either pro-life or a fundamentalist Christian.

She did it in a very low-key manner, I added, but I was totally blown out of the water. I mean one minute I thought I was having this fairly ordinary mother to mother bonding conversation and the next I was catapulted into this ideological war zone, this minefield in which I had no footing.

I've never thought of myself as falling into either category, I told him, but once she'd said that, I was totally unable to give a coherent reason as to why I'd had Fraser.

Totally unable to justify his birth.

I didn't know what to say.

Surely, it is a public health issue, she continued. Surely, there is a moral obligation on behalf of the mother to bring a healthy baby into society? And no, she didn't think amniocentesis should be paid for by the public health dollar simply for mothers to know whether or not their child had a disability. No, that would be a waste of taxpayers' money, it should only be available to those who agree to terminate.

When I gently tried to point out that some women who think they will terminate sometimes change their minds, while others find knowing in advance emotionally prepares them for the birth of a child with a disability, she remained unmoved. And once again stated that such tests should only be funded publicly if the woman agrees in advance to terminate. She also wondered how a feminist (if that was what I was) could've willingly burdened herself with a disabled child. Surely, I must realise, I am sending out the wrong message to young women.

Chris looked at me in disbelief. She didn't actually say those things did she? Well, not in such direct terms, it was all under the guise of a friendly intellectual feminist debate, I told him, but yes, she did articulate that position.

You didn't take her seriously, did you? He asked, his voice rising.

Hurt by what I perceived as a criticism of me, I told him I did understand where she was coming from, that as a woman I couldn't help but understand. But what upset me I told him, wanting him to be on my side, was that she could feel so free to judge me.
You don't know what it's like, I crumpled.

You don't know what it's like to know there are mothers out there who think I brought my difficulties on myself. That I chose to have a child with a disability.

I know I do a reasonably good job, an OK job, but it never looks like that. It only ever looks to them like I'm a failure. A woman who is constantly struggling, a woman who only ever says no. No I can't do that, no I can't join you. I can't go the park, to the movies, to the restaurant, to the beach. All I ever say is no. No, no, no.

I'm always on the outer, always different. And I hate being different, I whispered, tears beginning to roll down my cheeks; I just want to be normal.

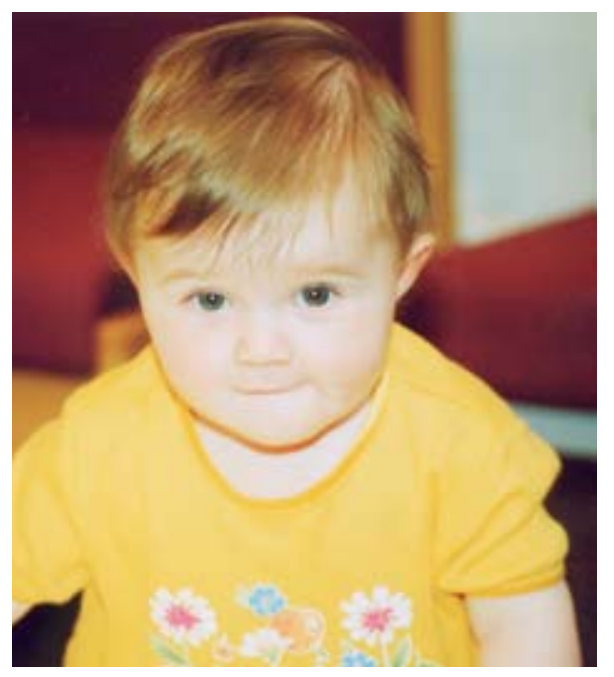

Christopher moved closer. Sometimes, I wept, sometimes I do wonder if I made the right decision. Sometimes I do resent how much it has affected our lives.

I paused, wondering if I had gone too far.

I was shocked by what I had said.

I was also frightened.

I had never ever said anything out loud like that before.

Did I really feel our lives were that bad? Did I really question my decision not to have had the amniocentesis? I couldn't believe what I was saying.

Christopher placed his arms around me. I didn't know it was that bad, he said gently.

But I could tell by his voice he was shocked.

Shocked either by my admission, or that other women could think that way about me. He remained still, his distress palpable. Are you sure, he asked, are you sure it 


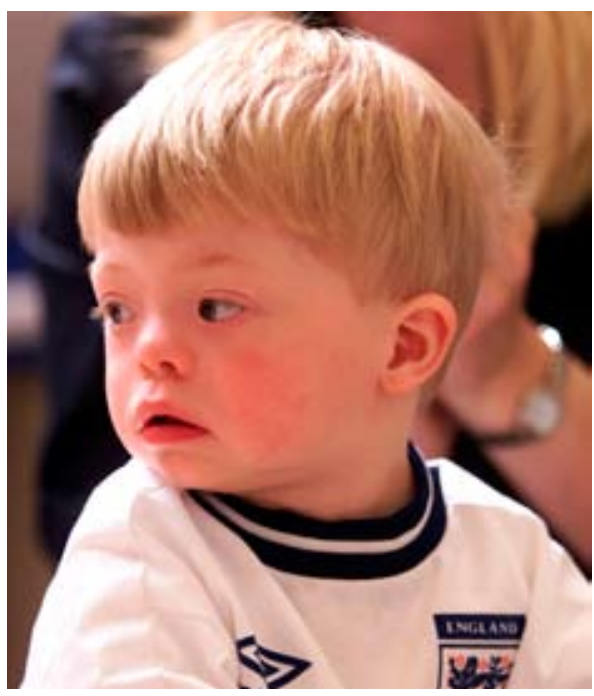

is that bad?

No, probably not, I've probably just over-reacted, but I am sure of one thing; I do know my situation confronts other women. That I always remind them of what can go wrong. Of what they're glad they've escaped. And they don't like me reminding them.

I paused, wiped my cheek and tried to calm myself.

I don't like always having to play that role, I told him. And it's made doubly difficult by the test. It's not like having a child with autism or cerebral palsy. Something that's seen as a tragedy, no my having a child with Down syndrome is seen as a choice. And because I chose it, I don't deserve any help, any support.

You do a great job, Christopher replied. A great job.

I wanted to respond, to tell him that I was so glad he could listen, that he could hear my doubts, but before I could get a word out there was a familiar noise. The sound of small hands opening our bedroom door.

It was Fraser, requesting to go to the DVD store. I smiled. He had dressed himself and even gotten his white sandshoes on the right feet. Back, he said, holding up a handful of DVDs. Back.

For that day my tears and introspection were over.

\section{Achieving ordinariness}

Talking to that woman that night did distress me. Deeply. But it also made me realise that there are probably larger reasons, larger forces at play which make it so hard for me to feel ordinary.

That unlike the children I nursed, the tragedies that befell Hannah and Samuel, that befell Rachel and Steve, that befell the parents and grandparents of Samuel, my tragedy - the birth of a child with Down syndrome - is singled out as preventable.

A tragedy/condition that medical researchers are working furiously to eliminate.

To eradicate.

With the expectant jubilation of an early non-invasive prenatal test at five or six weeks the only hyped up talk about Down syndrome. When, when, when will it be available is all anyone one wants to know.

I live in a world where there is rarely any public debate, rarely any public excitement surrounding issues such as how best to include children with Down syndrome, how best to promote innovative medical, social and educational research and how best to move forward.

Best is to eliminate. However for every woman who terminates a foetus with Down syndrome there is another like Victoria who is advised to take control of her future, is reassured by the test results and only later discovers their child has a disability. A developmental delay.

Victoria and I and many other mothers like us struggle to feel accepted. In part because the presence of genetic screening programmes is not conducive to creating an inclusive society. There is little welcoming of our children, little effort made to make us feel a little less lonely, a little lesson the outer.

Looking back I am glad I had that party conversation, glad I was pushed into such a dark place. Because if I hadn't wavered if I hadn't had that subsequent outburst with Christopher and admitted to feeling and thinking decidedly unpleasant thoughts, I don't think I would feel so good about Fraser today.

I have no doubts now; I simply cannot imagine life without my son. He is delightful. And more to the point I can no longer fathom any good reason why he shouldn't be here.

I am also far more aware of the context in which I am trying to parent a child with Down syndrome, the context in which I am trying to feel ordinary.

I can see how much the presence of the test complicates things. How much of a double-edged sword it has become. I also realise many other women may come to experience a similar pain and a similar sense of loneliness as more and more dis- abilities come to be perceived as preventable. As the drive towards detecting the less than best gains momentum.

It is easy to imagine how the list could grow. How conditions such as autism, ADHD, childhood leukaemia, schizophrenia, breast cancer and heart disease could be added.

One by one.

So in many ways I am grateful for the unpleasantness, grateful for the deep distress it caused. Because without being pushed and shoved I'm not sure I would've made us much progress as I have towards empowerment.

To feeling we can join in on our terms. To feeling I can be upfront with other mothers about Fraser, upfront about what I can and can't do, upfront about my limitations. Which in turn has helped to feel so much more ordinary.

\section{Imagining the future}

I don't know how I will feel once the noninvasive test to detect Down syndrome in the fifth or sixth week of pregnancy is available.

Hopefully, it won't make things worse. Make me seem less ordinary. Or make Fraser's future seem less assured, less secure. Hopefully the philosophy of inclusion will prevail for some time to come.

Whatever happens though at least now I know I made the right decision. The right decision for me. In fact I can still imagine myself refusing genetic testing if the only purpose is to terminate. And while this may be seen as a rejection of modernity, progress, equality, and even feminism, I would hope it could also be seen as a refusal to lose a sense of what it is to have developed your own personal ethical system - a value system that isn't simply defined by religious dogma, feminist ideology or the latest in public health policy. And that is an equally important message to send young women.

doi:10.3104/essays.2013

Fiona Place is a parent living in Australia.

(C) 2007 The Author. Journal Compilation (c) 2008 Down Syndrome Education International. www.downsed.org/copyright

Received: 20 September 2006; Accepted 14 February 2007; Published online: 7 August 2007. 